DOI:

УДК 351.743

\title{
Свген Неборський,
}

здобувач

Науково-дослідний інститут публічного

права (м. Київ)

ORCID:https://orcid.org/0000-0002-6783-2958

\section{ДІЯЛЬНІСТЬ СУБ’ЄКТІВ АДМІНІСТРАТИВНО-ПРАВОВИХ ВІДНОСИН У СФЕРІ МІСТОБУДУВАННЯ}

Досліджено методи діяльності суб 'єктів адміністративно-правових відносин у сфері містобудування. Зазначено, щзо державна політика у сфері будівництва повинна мати повноцінний інструментарій.

Зроблено висновок, щу серед найбільи досліджених методів правового регулювання, властивих для різних галузей права, визначають - імперативний та диспозитивний. Поряд із ичи для сфери містобудування характерне широке використання суб'єктами адміністративно-правових відносин диспозитивного методу. Водночас акиентовано увагу на поширеному застосуванні у практиці: імперативних, уповноважувальних, заохочувальних, рекомендаційних методів.

Виокремлено систему принципів діяльності суб'єктів адміністративно-правових відносин у сфері містобудування у вигляді двох блоків: а) загальні принцчипи; б) спеціальні принципи, які повинні бути визначені в будівельному законодавстві.

Ключові слова: суб’єкти, містобудування, принциии, методи, будівельна галузь, публічна адміністрація.

Бібл.: 11.

Неборский $\mathrm{E}$.

Методы и принципы деятельности субъектов административно-правовых отношений в сфере градостроительства

Исследованы методы деятельности субъектов административно-правовых отношений в сфере градострочтельства. Указано, что государственная политика в сфере строительства должна иметь полноценный инструментарий.

Сделан вывод, что среди наиболее исследованных методов правового регулирования присущих различным отраслям права определяют - императивный и диспозитивный. Наряду с этим для сферы градостроительства свойственно широкое использование субъектами административно-правовых отношений диспозитивного метода. Акиентировано внимание на распространенном применении в практике: императивных, управомачивающих, поощрительных, рекомендательных методов.

Выделены систему принципов деятельности субъектов административно-правовых отношений в сфере градостроительства в виде двух блоков: а) общчие принцииьы; б) специиальные принцииы, которые долюны быть определень в строительном законодательстве.

Ключові слова: суб 'єкти, містобудування, принцини, методи, будівельна галузь, публічна адміністрація.

Neborsky E.

Methods and Principles of Activity of Subjects of Administrative-Legal Relations in the Field of Urban Planning

In the article has been explored the methods of activity of subjects of administrative-legal relations in the field of urban development. It has been stated that state policy in the field of construction should have a complete toolkit: a system of means for transferring decisions, tracking their implementation, adjusting plans and measures, attracting the necessary material and human resources, evaluating the implementation of the policy.

There has been stated two views on the formation of methods, as a separate branch of law-town planning or construction law, or as methods in the field of urban planning with reference to the existing branch of law: administrative, economic, civil.

It has been concluded that among the most studied methods of legal regulation of the specific for different branches of law determine - imperative and dispositive. The imperative method is aimed at the emergence, alteration or termination of legal relations in the field of urban development and is implemented by the system of public authorities through enforcement which results in the issuance of a law enforcement act, the provision of which the subjects of these legal relations acquire specific legal rights and obligations.

Keywords: subjects, urban planning, principles, methods, construction industry, public administration.

(c) Євген Неборський, 2020 
Неборський $€$.

Діяльність суб'єктів адміністративно-правових відносин у сфері містобудування

Постановка проблеми. Якісна державна політика і належна реалізація прав та свобод у будь-якій сфері формуються за допомогою відповідних методів та принципів правового регулювання, а отже, і методів та принципів діяльності суб'єктів у тій чи іншій сфері.

Відповідно сфера містобудування також стикається з цим питанням. У сучасних умовах в Україні вкрай важливо мати чітку структуру методів та принципів діяльності всіх суб'єктів адміністративно-правових відносин у сфері містобудування, як підгрунтя належного виконання норм чинного законодавства та якісного виконання функцій означених суб'єктів, формування сприятливого середовища для розвитку галузі.

Аналіз останніх досліджень і публікацій. У науковій сфері проблематиці методів та принципів правового регулювання, методів та принципів діяльності приділяється окрема увага. В юридичній науці нерозривно пов'язують категорії форми та методу правового регулювання (публічного адміністрування для адміністративного права). Водночас зазначають, що якщо форму діяльності можна доволі чітко продемонструвати, показати іï правовий зміст і основне призначення, то іiі методи та принципи характеризуються меншим ступенем правової регламентації. Усе зазначене загалом свідчить про необхідність дослідження зазначеного напряму. Проблеми правового регулювання в галузі будівництва відображені у працях: Г. М. Гриценко, Е. Б. Кубко, І. О. Лугового, А. В. Матвійчук, І. М. Миронець, А. М. Мірошниченко, Г. Р. Мацюк, К. Б. Починок, В. О. Ромасько, Б. М. Семенко, Є. Ю. Соболь та інших вчених.

Більш предметно використовувалися праці науковців, спрямовані на адміністративно-правове регулювання будівельної галузі: О. В. Кудрявцева, А. В. Матвійчука, І. М. Миронець, К. Р. Резворович, В. О. Ромасько, О. В. Савицького, Б. М. Семенко та ін. У межах наукових пошуків були оглядово підняті питання щодо методів та принципів діяльності суб'єктів містобудування, зокрема предметом розгляду була юрисдикційна, публічно-сервісна, контрольно-наглядова діяльність зазначених суб'єктів. Незважаючи на це, комплексного розгляду суб' єктного складу в будівельній галузі на рівні окремого наукового дослідження немає, водночас не виокремлено як систему сукупність методів та принципів діяльності суб'єктів адміністративно-правових відносин у сфері містобудування.

Метою дослідження $є$ визначення методів та принципів діяльності суб’єктів адміністративноправових відносин у сфері містобудування. Завдання - визначити перелік методів діяльності суб'єктів адміністративно-правових відносин у сфері містобудування; дати узагальнювану характеристику кожного з виокремлених методів; визначити принципи діяльності суб'єктів адміністративно-правових відносин у сфері містобудування; запропонувати класифікацію принципів діяльності суб'єктів адміністративноправових відносин у сфері містобудування.

Виклад основного матеріалу дослідження. У статті сформульовано авторське бачення поняття методів діяльності суб'єктів адміністративно-правових відносин у сфері містобудування та наведено їхній перелік. Запропоновано принципи у досліджуваному напрямі представити у вигляді двох блоків: а) загальні; б) спеціальні.

Державна політика у сфері будівництва «повинна мати повноцінний інструментарій: систему засобів для передачі рішень, відслідковування їх виконання, коригування планів та заходів, залучення необхідних матеріальних і людських ресурсів, оцінки реалізації політики» [1, с. 170].

Взявши за основу наші попередні висновки щодо відносин у сфері містобудування, можемо констатувати - для регулювання відносин у цій сфері застосовується весь спектр методів правового регулювання зі збереженням їхньої відносної своєрідності. А якщо ми ведемо мову про формування окремої галузі права - містобудівне право, то звісно маємо говорити і про виокремлення галузевих методів правового регулювання.

3 огляду на це важливо розкрити питання щодо аналізу методів та принципів діяльності суб’єктів адміністративно-правових відносин у сфері містобудування.

Певна своєрідність методів діяльності суб'єктів адміністративно-правових відносин у сфері містобудування засвідчує поступове становлення відокремленої галузі права, однак наявна й спільність системи методів для всієї системи права. Серед найбільш досліджених методів правового регулювання, властивих для різних галузей права, визначають - імперативний та диспозитивний.

Імперативний метод спрямований на виникнення, зміну або припинення правовідносин у сфері містобудування. Він реалізується через систему органів публічної влади шляхом правозастосування, в результаті чого видається правозастосовчий акт, і згідно з його положенням суб'єкти зазначених правовідносин набувають специфічних юридичних прав та обов'язків. У сфері державного контролю та нагляду за дотриманням норм містобудівного права чітко визначені суб'єкти правовідносин - Державна 
архітектурно-будівельна інспекція та ії територіальні органи, містобудівні ради, органи та посадові особи місцевого самоврядування тощо наділяються компетенцією впливати на суб'єкта містобудування за допомогою імперативного методу правового регулювання.

Таким чином, імперативний метод застосовується в адміністративно-правових відносинах, що стосуються інтересів суспільства та держави, і формує гарантії дотримання прав та свобод людини і громадянина. Окрім цього за допомогою імперативного методу реалізуються принципи законності та верховенства права.

Водночас для сфери містобудування властиве широке використання суб'єктами адміністративноправових відносин диспозитивного методу.

Для врегулювання діяльності суб’єктів адміністративно-правових відносин у сфері містобудування на рівні окремих фізичних та юридичних осіб, як правило, застосовується диспозитивний метод. Для органів влади теж властиве застосування диспозитивного методу, який передбачає взаємодію 3 громадськістю щодо питань містобудування.

Можемо виокремити і загальноправовий підхід до системи методів, який також доволі поширений у практиці. У такому разі, як правило, виокремлюють такі базові методи, як імперативні, уповноважувальні, заохочувальні, рекомендаційні тощо. Безумовно, всі ці методи використовуються у правозастосовній практиці і теоретичні розробки науковців сприяють їх удосконаленню.

Однак недостатня увага з боку науковців, передусім теоретиків права, до певних специфічних (можна сказати галузевих) методів (контроль, перевірка, дотримання стандартів та інших) спричинила звуження кола наукових розробкок до переважно галузі адміністративного права. Водночас дуже часто простежуємо ситуацію, коли грунтовним науковим дослідженням окремих методів передує їх нормативне закріплення, тобто законодавець дуже часто скеровує вектор наукового пошуку.

Ми визнаємо той факт, що до нормопроєктної роботи залучаються і провідні науковці, й інститути громадянського суспільства, як передумова якісного нормативного матеріалу, що відповідатиме потребам суспільства. Однак, на нашу думку, цим процесам мають передувати комплексні наукові дослідження на рівні дисертаційних робіт чи монографій, конференції, круглі столи тощо.

Отже, проаналізована система методів правового регулювання та методів діяльності суб'єктів правовідносин у сфері містобудування є чіткою структурою, хоча і потребує подальшого наукового аналізу. Ми вбачаємо за доцільне максимально розширити предмет наукового аналізу «методи адміністративноправової діяльності» та залучити до його складу сукупність напрацьованих теорією та практикою методів.

Окрема увага в умовах державної політики, спрямованої на гуманізацію відносин у сфері «держава-суспільство», «держава-людина», має бути приділена тим методам, які стимулюють всіх учасників адміністративно-правових відносин до правомірної поведінки, з урахуванням та повагою до прав, свобод та законних інтересів інших суб'єктів, зокрема й у сфері містобудівної діяльності. В останні роки в нашій державі відчуваються значні позитивні зміни у цьому напрямку, хоча цей процес ще не завершений.

Вказаними методами насамперед мають бути такі:

1. Метод переконання. Можемо констатувати його ефективність у діяльності органів публічної адміністрації щодо формування позитивної відповідальності як суб’єктів впливу на формування та реалізацію містобудівної діяльності, так і об'єктів їхнього впливу. Серед заходів, що входять до цього методу, виокремлюємо вжиття роз'яснювальних, виховних, заохочувальних та інших заходів 3 метою дотримання вимог чинного законодавства.

Ми підтримуємо позицію науковців, що метод переконання (навчання; пропаганда, соціальна реклама, підвищення рівня правової свідомості та правової культури громадян, роз'яснення завдань і функцій публічної адміністрації; правове виховання; інструктажі; обмін передовим досвідом) «є пріоритетним методом впливу публічної адміністрації, оскільки використовується систематично, забезпечує добровільне виконання приписів» [2, с. 307].

2. Не менш ефективним є метод заохочення, що сприяє забезпеченню законності і дисципліни суб'єктів публічної адміністрації у сфері містобудування, а у відносинах з фізичними та юридичними особами через використання моральних і матеріальних заходів стимулює їх до правомірної поведінки. «За допомогою заохочення публічна адміністрація здійснює цілеспрямований вплив на інтереси осіб, формує їхню зацікавленість у здійсненні позитивних дій, чим спонукають громадян активізувати свої можливості» [2, c. 309].

У нормативно-правових актах закріплюються види заохочення, підстави їх застосування, повноваження публічної адміністрації в цій сфері. Тільки згідно із законами України визначаються 
Неборський $€$.

Діяльність суб'єктів адміністративно-правових відносин у сфері містобудування

державні нагороди. Конкретні заохочення вказуються також у нормативних актах, що регулюють суб’єкта публічної адміністрації. За способом впливу на осіб заохочення поділяють на:

1) моральні (подяка, грамота);

2) матеріальні (премія, цінний подарунок);

3) змішані (дострокове присвоєння рангу, призначення на вищу посаду);

4) статусні (присвоєння почесних звань, присвоєння навчальному закладу статусу національний тощо) [2, с. 311-313].

У межах наукової літератури виокремлюють методи та принципи діяльності окремих суб'єктів у сфері містобудування. Обсяг нашого дослідження не дає змоги детально виокремити методи діяльності окремого департаменту або управління, а тим більше їх посадових осіб, тому надамо узагальнену характеристику системи методів діяльності зазначеного блоку. По-перше, як вже зазначалося, для будьякого органу виконавчої влади (елементу системи) властивий той набір загальних методів діяльності, що й для усієї системи суб'єктів містобудування; в такому разі виокремлюємо такі методи діяльності суб'єктів адміністративно-правових відносин у сфері містобудування, як: переконання, заохочення та примус. Подруге, соціально-економічні та суспільно-політичні процеси впливають на розвиток системи методів діяльності як на науковому, так і на законодавчому рівні.

Так, в останнє десятиліття в нормативно-правовому вимірі в Україні закріплено специфічні методм діяльності суб'єктів у сфері публічного адміністрування, що все ще розвиваються, хоча окремі нормативно-правові акти могли втратити чинність, однак, як ми зазначали вище, вони формують вектори наукового дослідження, чим сприяють їхньому (методів) удосконаленню:

1) методологія, що пов'язана із збиранням та використанням адміністративних даних, - сукупність способів, правил і методів, які встановлюють порядок збирання, опрацювання, аналізу та використання адміністративних даних [3];

2) метод класифікації - спосіб об'єднання об'єктів класифікації в класифікаційні угруповання. Цей метод застосовується для розробки та впровадження національних класифікаторів. Сфера містобудування це широкий спектр застосування різноманітних класифікаторів, тому вбачаємо за необхідне долучити цей метод до переліку методів діяльності відповідних суб'єктів;

3) методологія містобудівного обгрунтування - вид містобудівної діяльності щодо формування документації, в якій відповідно до державних будівельних та інших норм, стандартів і правил, положень містобудівної документації визначаються містобудівні умови і обмеження забудови земельної ділянки (об'єкта будівництва), обов'язкові для врахування в процесі відведення земельної ділянки та / або проєктування об'єктів містобудування;

4) системність та інституціоналізм державного управління як метод ухвалення і обгрунтування рішень у сфері містобудування - передбачає комплексний, цілеспрямований державно-владний вплив;

5) метод делегування повноважень $є$ ефективним інструментарієм сучасного демократичного управління. В Україні наразі в рамках процесу децентралізації відбувається делегування повноважень від органів виконавчої влади органам місцевого самоврядування.

Сучасний стан містобудівного процесу в Україні визначається змінами в методиках аналізу і прогнозу розвитку містобудівних систем, оцінювання наслідків управлінських рішень, що тісно взаємопов'язане із соціально-економічними, політико-правовими, функціонально-територіальними, екологічними факторами та умовами функціонування і розвитку міст, тому створюються нові умови розвитку міської території, що потребують змін методів іiї аналізу, оцінювання й прогнозування ефективності землекористування [3, с. 1; 4].

Формування методів діяльності суб'єктів адміністративно-правових відносин у сфері містобудування безпосередньо пов'язано із системою принципів, на яких базується їхня діяльність.

Аналіз будівельного законодавства вказує про відсутність узгодженої між собою системи принципів діяльності суб'єктів адміністративно-правових відносин у сфері містобудування.

Для визначення системи принципів діяльності суб'єктів адміністративно-правових відносин у сфері містобудування потрібно враховувати ізсуб'єктний склад зазначених правовідносин та їхніх повноважень.

Відповідно до ст. 4 «Об’єкти та суб’єкти містобудування» Закону України «Про регулювання містобудівної діяльності» суб'єктами містобудування є органи виконавчої влади, Верховна Рада Автономної Республіки Крим, Рада міністрів Автономної Республіки Крим, органи місцевого самоврядування, фізичні та юридичні особи [6]. 
Аналізуючи зазначений суб’єктний склад, слід виокремити систему принципів, визначених у базових законодавчих актах, які регламентують їхню діяльність:

- Законі України «Про центральні органи виконавчої влади» від 17 березня 2011 року № 3166-VI статті 2 «Принципи діяльності міністерств та інших центральних органів виконавчої влади»;

- Законі України «Про місцеві державні адміністрації» від 09 квітня 1999 року № 586-XIV статті 3. «Принципи діяльності місцевих державних адміністрацій»;

- Законі України «Про місцеве самоврядування в Україні» від 21 травня 1997 року № 280/97-ВР стаття 4 «Основні принципи місцевого самоврядування».

Водночас будівельне законодавство не визначає базові засади, якіє відправною точкою в регулюванні діяльності суб'єктів містобудування. Зазначена позиція простежується навіть у проєкті Містобудівельного кодексу України [7], положення якого повинні бути спрямовані на установлення загальних правових та організаційних засад планування і забудови територій в Україні. Проте детальний аналіз змісту зазначеного кодифікованого акта вказує на а відсутність у ньому правових та організаційних засад діяльності суб'єктів містобудування.

Про виокремлення принципів, які б стосувалися загалом сфери містобудування, йдеться в проєкті Концепції публічного управління у сфері містобудування, в межах Аналітичної записки № 1 виокремлено «Принципи та ідеологічні засади Концепції», до яких віднесено принципи: законності; публічності; науковості; ефективності; плановості; субсидіарності та децентралізації [5, с. 66-67].

3 огляду на спеціальну літературу слід окреслити наукові погляди на види принципів, які торкаються сфери містобудування. Так, В. О. Резніченко виокремлює принципи дозвільної діяльності у сфері містобудування [6]. Б. М. Семенко деталізує саме принципи адміністративної відповідальності у будівельній галузі, виокремивши спеціалізовані принципи, притаманні саме досліджуваній галузі [7]. А. П. Хряпінський вважає за доцільне застосовувати принципи контрольно-наглядової діяльності у будівельній галузі [8].

Таким чином, серед науковців немає однозначної позиції щодо принципів у будівельній галузі загалом та принципів, притаманних саме діяльності суб'єктів адміністративних правовідносин у сфері містобудування.

Висновки. 3 огляду на вищезазначене виникає необхідність виокремити систему принципів діяльності суб'єктів адміністративно-правових відносин у сфері містобудування, згрупувавши ії у вигляді двох блоків: а) загальні принципи, які визначають загальні положення діяльності органів публічної влади та базуються на правових та організаційних положеннях законів України «Про центральні органи виконавчої влади», «Про місцеве самоврядування», «Про місцеві державні адміністрації», «Про державну службу»; б) спеціальні принципи, які повинні бути визначені в будівельному законодавстві.

Отже, методи діяльності суб’єктів адміністративно-правових відносин у сфері містобудування - це сукупність способів, прийомів та засобів публічно-владного впливу органів (посадових осіб) публічної адміністрації на суспільство, поведінку (діяльність) уповноважених підпорядкованих суб'єктів, фізичних та юридичних осіб у сфері містобудівної діяльності, з метою їх упорядкування та забезпечення сталого поступального розвитку, для максимально ефективного забезпечення інтересів суспільства, держави та прав і свобод людини й громадянина.

\section{Список використаних джерел}

1. Резворович К. Р. Адміністративно-правове забезпечення реалізації державної політики у сфері будівництва : дис. ... канд. юрид. наук : 12.00.07. Київ, 2016. 194 с.

2. Курс адміністративного права України : підручник / за ред. О. В. Кузьменко. 3-тє вид., допов. Київ : Юрінком Інтер, 2018. 904 с.

3. Методологія, що пов'язана із збиранням та використанням адміністративних даних. URL : https://zakon. rada.gov.ua/laws/term/15277 (дата звернення: 10.12.2019).

4. Про затвердження Порядку надання вихідних даних для проектування об'єктів містобудування : Постанова Кабінету Міністрів України від 20.05.2009 № 489.

5. Мещеряков В. В. Містобудування як складова управління територіальним розвитком міста. Державне управління: удосконалення та розвиток. 2012. № 9. URL : http://www.dy.nayka.com.ua/?op=1\&z=469 (дата звернення: 12.12.2019).

6. Про регулювання містобудівної діяльності від 17 лютого 2011 року № 3038-VI. Відомості Верховної Ради Украӥни. 2011. № 34. Ст. 343.

7. Проект Містобудівельного кодексу України від 18 травня 2010 року № 6400. URL : http://w1.c1.rada.gov. ua/pls/zweb2/webproc4_2?pf3516=6400\&skl=7 (дата звернення: 14.12.2019). 
Неборський $€$.

Діяльність суб'єктів адміністративно-правових відносин у сфері містобудування

8. Концепція публічного управління у сфері містобудівної діяльності : зб. аналіт. матеріалів. Київ, 2019. 369 c.

9. Резніченко В. О. Адміністративно-правові засади дозвільної діяльності у сфері містобудування : дис. ... канд. юрид. наук : 12.00.07. Харків, 2005. 198 с.

10. Семенко Б. М. Адміністративна відповідальність за правопорушення у галузі будівництва : дис. ... канд. юрид. наук : 12.00.07. Запоріжжя, 2011. 193 с.

11. Хряпинський А. П. Адміністративно-правові засади контрольнонаглядової діяльності у сфері містобудування : дис. ... канд. юрид. наук : 12.00.07. Херсон, 2014. 198 с.

\section{References:}

1. Rezvorovych, K. R. (2016). Administratyvno-pravove zabezpechennia realizatsii derzhavnoi polityky u sferi budivnytstva [Administrative and legal support for the implementation of state policy in the field of construction]: Candidate's thesis. Kyiv [in Ukrainian].

2. Kuzmenko, O. V. (2018). Kurs administratyvnoho prava Ukrainy: pidruchnyk [Course of Administrative Law of Ukraine: textbook]. Kyiv: Yurinkom Inter [in Ukrainian].

3. Metodolohiia, shcho poviazana iz zbyranniam ta vykorystanniam administratyvnykh danykh [Methodology related to the collection and use of administrative information]. Retrieved from https://zakon.rada.gov.ua/ laws/term/15277 [in Ukrainian].

4. Pro zatverdzhennia Poriadku nadannia vykhidnykh danykh dlia proektuvannia obiektiv mistobuduvannia [On approval of the Procedure for providing initial data for the design of urban development objects]: Postanova Kabinetu Ministriv Ukrainy vid 20.05.2009 № 489. Retrieved from https://zakon.rada.gov.ua/laws/show/4892009-\%D0\%BF [in Ukrainian].

5. Meshcheriakov, V. V. (2012). Mistobuduvannia yak skladova upravlinnia terytorialnym rozvytkom mista [Urban planning as a component of managing the territorial development of a city]. Derzhavne upravlinnia: udoskonalennia ta rozvytok - Public Administration: Improvement and Development, 9. Retrieved from http:// www.dy.nayka.com.ua/?op=1\&z=469 [in Ukrainian].

6. Pro rehuliuvannia mistobudivnoi diialnosti [On regulation of urban development activity]: Zakon Ukrayni vid 17.02.2011 r. № 3038-VI. (2011). Vidomosti Verkhovnoi Rady Ukrainy - Bulletin of Verkhovna Rada of Ukraine, 34, 343.

7. Proekt Mistobudivnoho kodeksu Ukrainy vid 18.05.2010 r. №6400 [Draft Urban Planning Code of Ukraine of May 18, 2010 No 6400]. Retrieved from http://w1.c1.rada.gov.ua/pls/zweb2/webproc4_2?pf3516=6400\&skl=7 [in Ukrainian].

8. Kontseptsiia publichnoho upravlinnia u sferi mistobudivnoi diialnosti: zb. analit. materialiv [The concept of public management in the field of urban development] (2019). Kyiv [in Ukrainian].

9. Reznichenko, V. O. (2005). Administratyvno-pravovi zasady dozvilnoi diialnosti u sferi mistobuduvannia [Administrative and legal principles of permitting activities in the field of urban planning]: Candidate's thesis. Kharkiv [in Ukrainian].

10. Semenko, B. M. (2011). Administratyvna vidpovidalnist za pravoporushennia u haluzi budivnytstva [administrative responsibility for offenses in the field of construction]: Candidate's thesis. Zaporizhzhia [in Ukrainian].

11. Khriapynskyi, A. P. (2014). Administratyvno-pravovi zasady kontrolnonahliadovoi diialnosti u sferi mistobuduvannia [Administrative-legal bases of supervisory activity in the field of urban planning]: Candidate's thesis. Kherson [in Ukrainian]. 